\title{
ON SOME NEW SPECIES OF BRITISH EOCENE GASTROPODA, WITH REMARKS ON TWO FORMS ALREADY DESCRIBED.
}

By R. Bullen Newton, F.G.S., etc.

Read June 14th, 1895.

\section{Pl. XXII.}

Авошт the year 1850, the late Mr. Edward Charlesworth, then occupying the position of Curator to the York Museum, interested himself in the study of some of the more minute forms of English Tertiary Mollusea which he had obtained mainly from the Upper Eocene beds of Barton, in Hampshire. Under the auspices of the British Natural History Society of York, he issued single specimens of these small shells to the public, in glazed frames, accompanied by wellexecuted and enlarged lithographic drawings prepared from nature by a Mr. William Smith. The material thus selected represented not only described species, but also included others which were entirely new, and to which certain names were attached, descriptions being promised in due course to substantiate the manuscript determinations. These descriptions, however, never appeared, so that the unpublished names, although largely quoted in the literature of this country and abroad, retain up to the present time very little scientific value.

Some Gastropods forming part of this series, formerly in the possession of the late Mr. Frederick Harford, and now in the British Museum, have recently been examined, with the result that seven new species have been determined, belonging to various genera, whilst two others have been recognized as established forms. Thinking that perhaps Charlesworth's type specimens might be in the York Museum, I communicated with the Keeper of that institution, Mr. M. Platnauer, who most obligingly sent me all the specimens preserved there for examination. This material, however, did not appear to include these types any more than that acquired by the British Museum; and since the specimens had somewhat deteriorated, I have drawn up the following descriptions from better preserved examples of the same shells in the Edwards and general collections in the British Museum, and have had new illustrations prepared showing more accurate details than those originally issued by the British Natural History Society of York. Care has been taken to adopt Charlesworth's specific names, except where some valid reason has necessitated their rejection.

\section{Odostomia lirifera, n.sp. Pl. XXII, Figs. 1, 2.}

Odostomia turgida, Charlesworth MS., Morris, Cat. British Fossils, 1854, ed. 2, p. 265 (non Sars, 1878).

Shell smooth, turriculate, ventricose; apex obtuse; composed of four or five moderately wide whorls, the last of large size and convex, the others with rather depressed sides; suture oblique, canaliculated; 


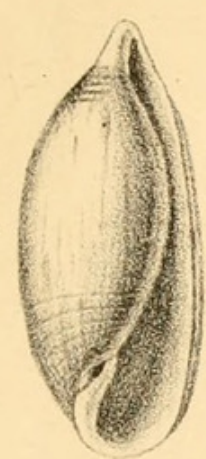

13
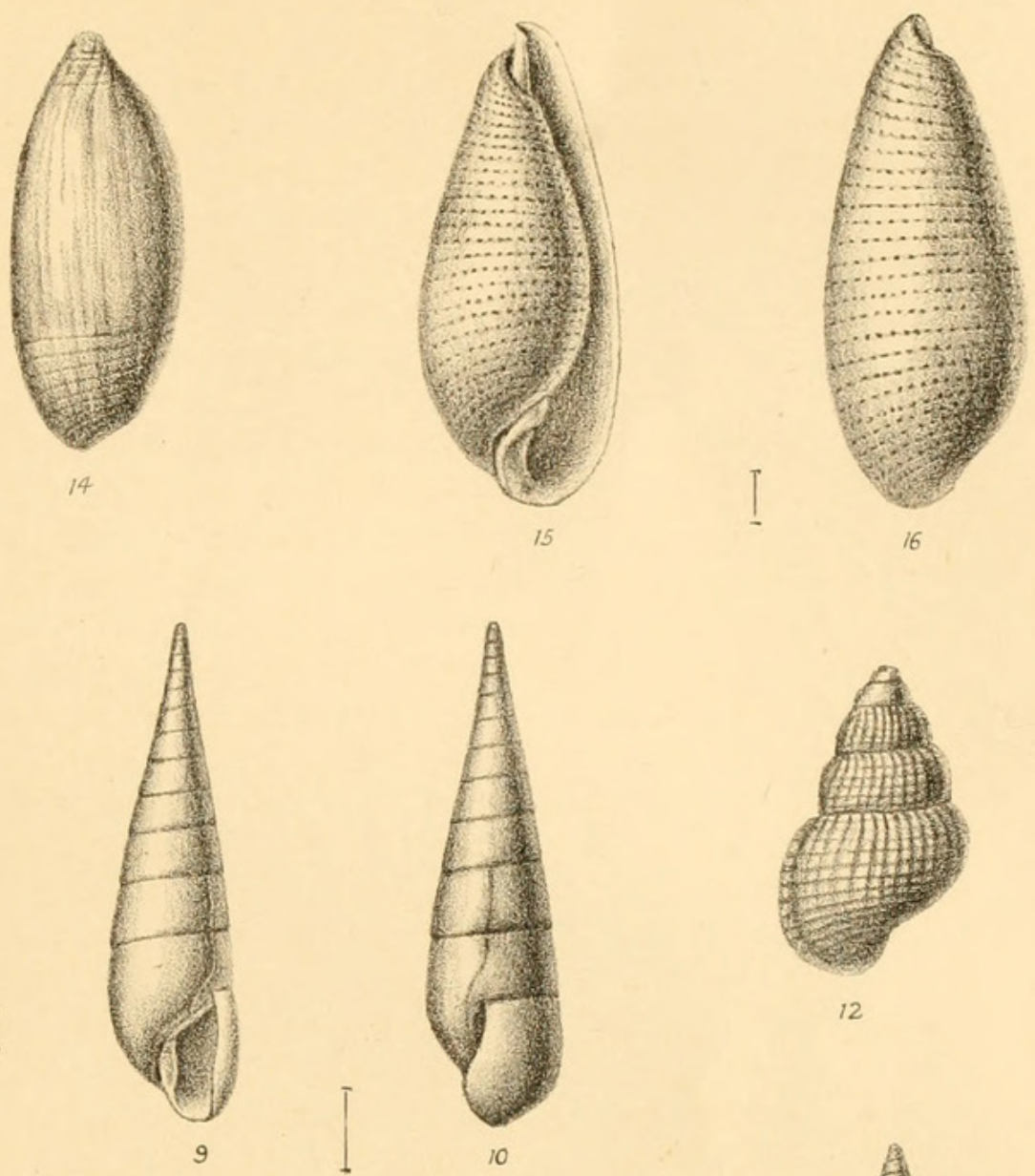

12
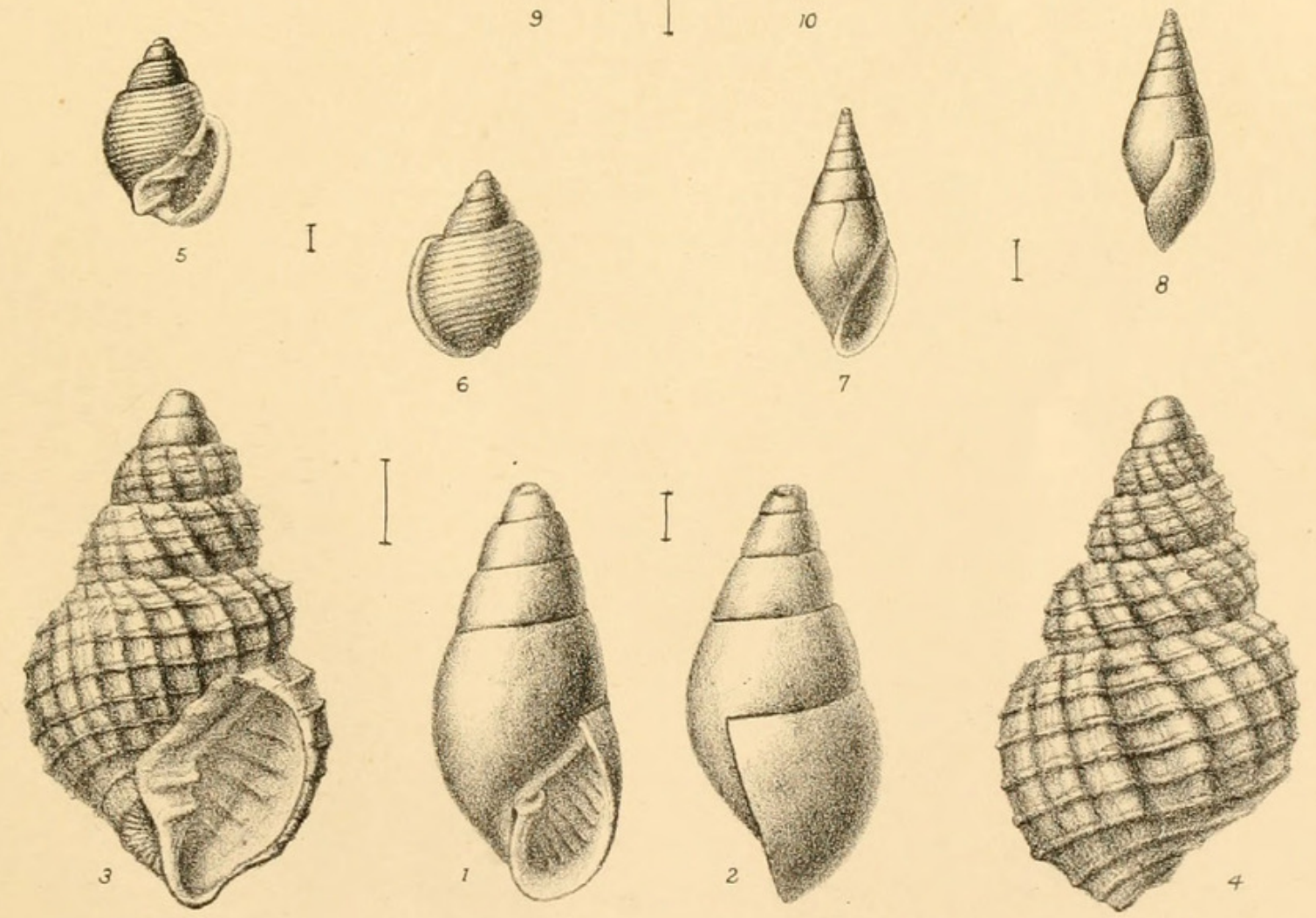

Berjeau\& Highley del.et lith .

Hanhart imp

British Eocene Gastropoda 

aperture acutely ovate, oblique, anteriorly wide and laterally expanded; columella with a strongly twisted fold, having behind an obscure umbilical perforation; labrum acutely margined and bearing interiorly eight prominent, ridge-like, equidistant plications. Dimensions: alt. 4, diam. $2 \mathrm{~mm}$.

This species is characterized by the small number of its volutions, by the great size of the body-whorl, and by the plications on the inner surface of the labrum. The French Eocene forms of this genus, such as 0 . minor, Desh., O. hordeola, Lam., or O. pyramis, Desh., show the same sculptured character of the labrum, though at the same time they possess a greater number of whorls than the English form. It is perhaps more closely allied to $O$. Lapparenti, De Raincourt, from the Paris Basin, which is also rentricose, though having more plications in the labrum and a less prominent fold on the columella; it also differs from 0 . pingue, Von Könen, of Oligocene age, from North Germany, in its much longer body-whorl and in its general contour and size.

This is apparently a rare species, only one or two examples being: known.

Formation.-Upper Eocene (Barton Beds).
Localities.-Barton (type) and High Cliff, Hants.

Cancellaria microstoma, n.sp. Pl. XXII, Figs. 3, 4.

Cancellaria microstoma, Charlesworth MS., Morris, Cat. British Fossils, 1854, ed. 2, p. 239; R. B. Newton, Syst. List Edwards Coll. British Museum, 1891, p. 171.

Shell small, elongate, umbilicated; apex obtuse; consisting of six moderately convex and deeply sutured whorls, the two initial ones being smooth, the remainder strongly marked with varices and encircled by regular concentric lines; last whorl rather longer than half the entire axis of shell; aperture small, oval, with a short, narrow, and slightly curved anterior canal; labrum thickened by the last varix, serrated, with a feeble anterior sinus, and bearing five or six elongate plications on its inner surface; columella border callous, reflected, possessing two nearly horizontal plaits; umbilical cavity infundibuliform, small and radiately striated. Dimensions: alt. $7 \mathrm{~mm}$.; diam. nearly $4 \mathrm{~mm}$.

Several examples of this species, occurring in both Barton and Bracklesham deposits, are represented in the British Museum, so it may be regarded as fairly common. It differs from Cancellaria evulsum (Solander), found in similar beds, in having two instead of three columella plications, in possessing an umbilicus, in its narrower anterior canal, and in being furnished with fewer plications within the labrum. From the French specimen $C$. Bezanconi, De Raincourt, it is also removed by reason of its smaller aperture, its curved canal, and the presence of the sinus on the outer lip.

The genus Cancellaria has been specially studied by such authorities as Adams, Jousseaume, Sacco, etc., who have divided off its many species under various genera. The present form might be recognized as belonging to M. Cossmann's sectional group of Sveltella, though temporarily I prefer to regard it as a true Cancellaria. 
Formations and Localities.-Upper Eocene (Barton Beds): Barton, Hants (type); Alum Bay (No. 29 bed), I. of Wight. Middle Eocene (Bracklesham Beds): Bracklesham Bay, Sussex; Brook and Bramshaw, in the New Forest.

\section{Ringicula parva, n.sp. Pl. XXII, Figs. 5, 6.}

Ringicula parva, Charlesworth MS., Morris, Cat. British Fossils, 1854, ed. 2, p. 276; Lowry, Etheridge, and Edwards, Chart Characteristic British Tert. Fossils, 1866.

Ringicula Bezanconi, R. B. Newton, Syst. List Edwards Coll. British Museum, 1891, p. 262 (non Morlet).

Shell small, globose; consisting of four whorls regularly and concentrically grooved, but having a smooth and mammillated summit; whorls with slightly convex sides, the last one of prominent length and very ventricose; suture sub-canaliculate; aperture wide, contracted above and emarginate in front; columella callous, bearing three lamelliform plications, two being very anterior and nearly horizontal, the third posterior and shorter; labrum thick, dilated, not extending to the suture, furnished with obscure dentations within and outwardly having a smooth rounded rim; the columella and labrum unite at both extremities. Dimensions: alt. 2, diam. 1.5 mm.

In comparing this shell with Morlet's Ringicula Bezanconi, from France, it is found to differ mainly in having a somewhat smaller aperture, caused by the posterior end of the labrum being remote from the suture; a greater space also exists between the labrum and suture in $R$. ringens, Lam., which is besides smaller and less conical ; $R$. minor, Desh., is further removed from our species by reason of its more produced spire, deeper anterior sinus, and less globose form.

Formation.-Upper Eocene (Barton Beds).

Localities.-Barton and High Cliff (type), Hants.

\section{Eulma macrostoma, n.sp. Pl. XXII, Figs. 7, 8.}

Eulima macrostoma, Charlesworth MS., Morris, Cat. British Fossils, 1854, ed. 2, p. 247 ; R. B. Newton, Syst. List Edwards Coll. British Museum, 1891, p. 183.

Shell small, composed of seven whorls; apex acute; whorls with rather depressed sides, the last very long and centrally ventricose; suture distinct, slightly oblique ; aperture narrow, elongate, and attenuated in front; labrum arched, curved at the suture, margin thin; columella long, reflected, and oblique; surface polished, porcellanous, smooth, with frequently obscure cicatrices on one side of the spire. Dimensions: alt. 3, diam. $1 \mathrm{~mm}$.

In comparing this species with $E$. concinna, Desh., from the Paris Basin, M. Cossmann ${ }^{1}$ remarks that it is distinguishable by being more ventricose and more prominently arched at the labrum. It can also be recognized from all other forms by the large size of the body-whorl, which measures rather more than half the entire length of axis, by its long aperture, and by the deeply curved sinuation at the suture. The

1 Ann. R. Soc. Malac. Belgique, xxiii, 1888, p. 116. 
obscure cicatrice, observable on one side of the shell only, indicates the right position of this species to be among the true Eulima, and not with Subularia of Monterosato (=Leiostraca, H. and A. Adams), which is characterized by the presence of a cicatrice on each side of the spire. This shell is well represented in the British Museum.

Formation.-Upper Eocene (Barton Beds).

Localities.-Barton and High Cliff (type), Hants.

Eulma politissma, n.sp. Pl. XXII, Figs. 9, 10.

Eulima polygyra, Charlesworth MS., Morris, Cat. British Fossils, 1854, ed. 2, p. 247, non A. Adams, 1850 ; Lowry, Etheridge, and Edwards, Chart Characteristic British Tertiary Fossils, 1866.

Eulima, sp., R. B. Newton, Syst. List Edwards Coll. British Museum, 1891, p. 184.

Shell narrowly elongate, smooth, porcellanous, with about twelve whorls; spire long, acuminate, slightly flexuous, with an obscure varix on one side; last whorl rounded, remainder flattened; suture distinct and rather oblique; aperture narrow and acutely ovate; base moderately effuse; columella border reflected, nearly parallel with axis of shell; labrum obtuse, subemarginate behind, centrally dilated. Dimensions: alt. $6.5 \mathrm{~mm}$. ; diam. $\max .1 .5 \mathrm{~mm}$.

The new species here described has hitherto been listed under the MS. name of Eulima polygyra, but that having been used by A. Adams for another shell, it is now changed to $E$. politissima. It resembles both E. munda, Desh., and E. turgidula, Desh., from the French Eocenes, though differing from the former in its curved and subemarginate labrum; whilst from the latter it is separable on account of its more slender and narrow form, more elongate terminal volution, and its larger number of whorls.

This is evidently a fairly common species, several examples being known.

Formation.-Upper Eocene (Barton Beds).

Localities.-Barton and High Cliff (type), Hants.

Alvania Bartonensis, n.sp. Pl. XXII, Figs. 11, 12.

Rissoa Bartonensis, Charlesworth MS.

Rissoina Bartonensis, Lowry, Etheridge, and Edwards, Chart Characteristic British Tertiary Fossils, 1866.

Rissoa Bartonensis, Charlesworth MS., R. B. Newton, Syst. List Edwards Coll. British Museum, 1891, p. 231.

Shell small, perforated by a thin umbilical chink situated behind the columella, globose, turbinate; consisting of five or six ventricose and deeply sutured whorls; apex obtuse; aperture ovate, entire; outer lip dilated and thickened marginally by an external varix; surface ornamented with an extremely fine cancellate structure, except on the two initial whorls, where it is smooth. Dimensions: alt. $2 \cdot 5$, diam. $1 \cdot 5 \mathrm{~mm}$.

This shell was originally recognized under the genus Rissoia, but it is here regarded as belonging to Risso's Alvania, because of its 
convexity, cancellated surface, and thickened labrum. It differs also from Rissoina, which is long and turreted, and slightly canaliculate in front. The species approaches Rissoia Barreti of Morlet, from the Paris Basin, but appears to be more ventricose and with a rather more prominent suture. It is also related to $R$. tenuisculpta, Boettger, from the German Oligocene, as pointed out by Prof. Von Könen, ${ }^{1}$ but the reticulate markings of the surface are finer and more closely set, the foreign species being distinctly costulate, as in the true Rissoia.

Formation.-Upper Eocene (Barton Beds).

Localities.-Barton and High Cliff (type), Hants.

Volvulella Charlesworthi, n.sp. Pl. XXII, Figs. 13, 14.

Volvula redacta, Lowry, Etheridge, and Edwards, Chart Characteristic British Tertiary Fossils, 1866, non Deshayes.

Bulla acuminata, Charlesworth MS., non Bruguière nec J. de C. Sowerby.

Volvulella Charlesworthi (Edwards MS.), R. B. Newton, Syst. List Edwards Coll. British Museum, 1891, p. 268.

Shell elongate, subcylindrical, centrally ventricose; surface smooth in the middle, obscure spiral striations on the terminal portions, with occasional fine longitudinal lines of growth; perforated by a narrow chink-like umbilicus; mouth linear, narrow posteriorly, produced and widest in front; labrum acute and arched; columella border curved, with a prominent fold at its base, behind which is the umbilicus; apical rostrum acuminate and only moderately produced. Dimensions: alt. 3 , diam. $2 \mathrm{~mm}$.

This species was mistaken by Charlesworth for Bruguière's Bulla acuminata, the type of Tolvulella, which ranges from Pliocene to recent times: a form with a more slender contour, a less prominent plication, and a more pointed apex.

It is easily distinguishable from $V$. extensa, J. de C. Sby., or $V$. lanceolata, J. de C. Sby., species which differ from it not only in shape but in possessing a continuous spiral sculpture. The French Eocene forms of this genus also show points of difference from the present species: $V$. rostralina, Cossmann, has a very produced rostrum; $V$. radius, Desh., is conoidal, and has only a moderately developed rostrum; whilst $V$. redacta, Desh., is distinguished by its completely smooth surface, without any evidence of spiral striæ.

Formation.-Upper Eocene (Barton Beds).

Localities.-Barton and High Cliff (type), Hants.

Volvulella lanceolata, J. de C. Sowerby. Pl. XXII, Figs. 15, 16. Bulla hastula, Charlesworth MS.

Bulla lanceolata, J. de C. Sby., Dixon's Geology and Fossils of Sussex, 1850, p. 177 , pl. vii, fig. 7.

Bulla (Volvula) lanceolata, Lowry, Etheridge, and Edwards, Chart Characteristic British Tertiary Fossils, 1866.

1 Abhandl. Geol. Spec. Kart. Preussen, 1892, vol. x, pt. 4, p. 823, pl. lv, fig. 1. 


\section{$2 \mathrm{BHL}$ Biodiversity Heritage Library}

1895. "ON SOME NEW SPECIES OF BRITISH EOCENE GASTROPODA, WITH REMARKS ON TWO FORMS ALREADY DESCRIBED." Proceedings of the Malacological Society of London 1, 326-332.

View This Item Online: https://www.biodiversitylibrary.org/item/52295

Permalink: https://www.biodiversitylibrary.org/partpdf/202616

\section{Holding Institution}

Smithsonian Libraries

\section{Sponsored by}

Smithsonian

\section{Copyright \& Reuse}

Copyright Status: Public domain. The BHL considers that this work is no longer under copyright protection.

This document was created from content at the Biodiversity Heritage Library, the world's largest open access digital library for biodiversity literature and archives. Visit BHL at https://www.biodiversitylibrary.org. 